\title{
Haemoglobin K Woolwich: a study of the family of a homozygote
}

\author{
R CABANNES*, P AMEGNIZIN*, A SANGARE*, D ARNE*, \\ R CASEY $\dagger$, AND H LEHMANN $\ddagger$
}

From the *Department of Immunohaematology, Faculty of Medicine, National University of the Ivory Coast, BP V166, Abidjan; †The John Innes Institute, Colney Lane, Norwich NR4 7UH; and the $\ddagger$ Department of Biochemistry, University of Cambridge, Tennis Court Road, Cambridge CB2 1QW, UK

SUMMARY A family is described in which the proband is homozygous and several relatives are heterozygous for $\mathrm{Hb} \mathrm{K}$ Woolwich $(\beta 130$ [H10] Lys $\rightarrow \mathrm{Gln})$. These people are clinically and haematologically normal. The relationship between the presence of $\mathrm{Hb} \mathrm{K}$ Woolwich and $\beta^{+}$-thalassaemia is discussed. The distribution of $\mathrm{Hb} \mathrm{K}$ Woolwich in West Africa is discussed and it is seen to be closely associated with the Akan group.

Haemoglobin $\mathrm{K}$ Woolwich (Hb KW) was first described in a West Indian family ${ }^{1}$ and was then described from Nigeria ${ }^{2}$ and Ghana, ${ }^{3}$ mainly in the heterozygous form but also in double heterozygous combination with $\mathrm{Hb} \mathrm{S}$ or $\mathrm{Hb} \mathrm{C}$.

In the Ivory Coast it has been seen from 1969 and it is in this part of Africa that most of the subjects with $\mathrm{Hb} \mathrm{KW}$ are observed. ${ }^{4}$ We have now studied a family of which six members are heterozygotes for $\mathrm{Hb} \mathrm{KW}$ and one is a $\mathrm{Hb} \mathrm{KW}$ homozygote.

\section{Methods}

Blood samples were collected in EDTA or in ACD and transported on ice to Abidjan. Routine haematological studies were done using standard methods. Reticulocytes were counted after incubating blood with brilliant cresyl blue. Serum iron was measured by the Meckotest method and glucose-6-phosphate dehydrogenase activity by the technique of Motulsky Received for publication 16 July 1979 and Campbell-Kraut. ${ }^{5}$ Blood grouping was done by standard methods, using test sera from the Centre National de Transfusion de Paris. All the methods were those recommended by the International Committees for Standardization in Haematology (1975).

Initial identification of haemoglobin variants was made by cellulose acetate (cellogel) electrophoresis in tris-EDTA-borate buffer, $\mathrm{pH} 8.9$ to $9,{ }^{6}$ and by agar gel electrophoresis in citrate buffer, $\mathrm{pH} 6 \cdot 1 .^{7}$

Separation of globin chains by cellulose acetate electrophoresis was carried out in urea-mercaptoethanol ${ }^{8}$ or PCMB. $^{9}$

$\mathrm{Hb} \quad \mathrm{A}_{2}$ was measured by elution after electrophoresis on cellogel, and by microcolumn chromatography on DEAE-cellulose. ${ }^{10}$ Alkali resistant $\mathrm{Hb}$ was evaluated by the method of Singer et al. ${ }^{11}$

The haemoglobin solubility was tested by the method of Itano ${ }^{12}$ and the heat stability by the isopropanol method. ${ }^{13}$

- Globin was prepared from the total haemolysate obtained from III.3 (fig 1) by acid acetone

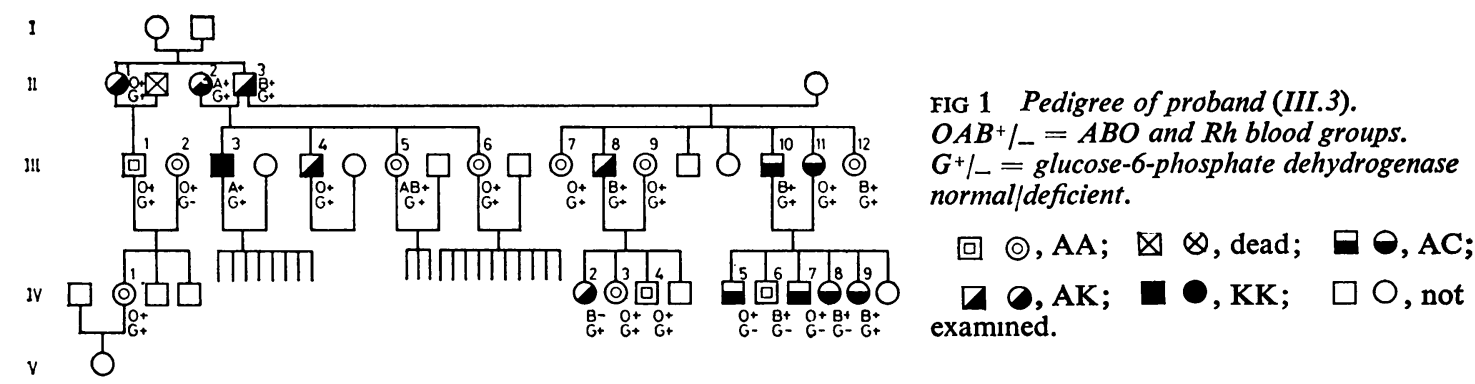


precipitation. A small portion of the globin was digested with trypsin and the remainder was separated into $\alpha$-, $\beta$-, and $\delta$-chains according to Clegg et al. ${ }^{14}$ The isolated chains were dialysed against $0.5 \%(\mathrm{v} / \mathrm{v})$ aqueous formic acid at $4^{\circ} \mathrm{C}$ and recovered by freeze drying. Fingerprints of the soluble tryptic peptides were prepared from both the unmodified $\beta$-chain and the total globin and were stained with ninhydrin and reagents for specific amino-acid residues. $^{15}$ Relevant peptides were eluted from lightly stained preparative fingerprints and hydrolysed in sealed tubes at $108^{\circ} \mathrm{C}$ for 24 or 48 hours with constant boiling $\mathrm{HCl}$ containing $1 \%(\mathrm{w} / \mathrm{v})$ phenol. Where necessary, peptides were purified by paper electrophoresis at $\mathrm{pH} 3.5(53 \mathrm{~V} / \mathrm{cm}, 2 \mathrm{~h})$ before elution and hydrolysis. After removal of the $\mathrm{HCl}$ in vacuo, the hydrolysates were analysed using a Locarte amino-acid analyser.

\section{Results}

The fingerprints of the soluble tryptic peptides of the total globin from III.3 showed that peptides $\beta^{\mathrm{A}} \mathrm{TpXIII}$ and $\beta^{\mathrm{A}} \mathrm{TpXIV}$, which normally give staining reactions for tyrosine and histidine, respectively, were both absent, indicating the absence of normal $\mathrm{Hb} \mathrm{A}$ from the total haemolysate of III.3. This was confirmed by CM-cellulose chromato-

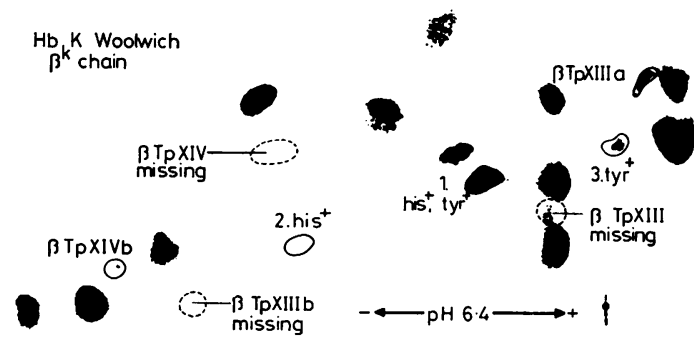

FIG 2 Fingerprint of the soluble tryptic peptides from the $\beta$-chain of $\mathrm{Hb} \mathrm{K}$ Woolwich. ! indicates point of application. graphy of the total globin from III.3, which showed that all the $\beta$-chains present in the sample eluted earlier than normal $\beta^{A}$-chains.

The fingerprint of the soluble tryptic peptides from these $\beta$-chains also showed the absence of $\beta^{A}$ TpXIII and $\beta^{A}$ TpXIV and the presence of a new peptide containing histidine and tyrosine (peptide 1 in fig 2). This suggested that the haemoglobin was Hb K Woolwich ( $\beta 132$ [H10] Lys $\rightarrow$ Gln), in which there can be no tryptic hydrolysis at position $\beta 132$ and in which $\beta^{A} \mathrm{TpXIII}$ and $\beta^{\mathrm{A}} \mathrm{TpXIV}$ are replaced by $\beta$ k TpXIII-XIV (see fig 3).

Amino-acid analysis of the peptide 1 (table 1) confirmed that the composition was that of residues $\beta 121$ to 144 but with only one lysine and with an additional glutamic acid. The electrophoretic mobility of the haemoglobin (and of the abnormal peptide) indicated that lysine must have been substituted by glutamine (which is converted to glutamic acid during acid hydrolysis).

The following additional features of the fingerprint are worthy of mention.

(1) The minor dipeptide $\beta$ TpXIIIb ( $\beta 131$ to 132 , Gln - Lys) which results from hydrolysis on

TABLE 1 Amino-acid analyses of peptides 1, 2, and 3 from $\mathrm{Hb} \mathrm{K}$ Woolwich

\begin{tabular}{|c|c|c|c|c|}
\hline $\begin{array}{l}\text { Amino- } \\
\text { acid }\end{array}$ & $l$ & $\begin{array}{l}\text { Expected for } \\
\beta^{\mathbf{A}} \mathrm{TpXIII}+\beta^{\mathbf{A}} \mathrm{TpXIV}\end{array}$ & 2 & 3 \\
\hline Asp & $1 \cdot 1$ (1) & 1 & $1 \cdot 1(1)$ & $1 \cdot 2(1)$ \\
\hline Thr & 1.0 (1) & 1 & & 0.9 (1) \\
\hline Glu & $3 \cdot 8(4)$ & 3 & $2 \cdot 1(2)$ & 3.8 (4) \\
\hline Pro & $2.0(2)$ & 2 & & $1 \cdot 9(2)$ \\
\hline Gly & $1 \cdot 2(1)$ & 1 & $1 \cdot 3(1)$ & $1 \cdot 3(1)$ \\
\hline Ala & $6 \cdot 3(6)$ & 6 & $3 \cdot 7$ (4) & $4 \cdot 1$ (4) \\
\hline Val & 3.9 (4) $\dagger$ & 4 & $2.5(3)^{*}$ & $4 \cdot 2(4) \dagger$ \\
\hline Leu & $1 \cdot 0$ (1) & 1 & $1 \cdot 2(1)$ & \\
\hline Tyr & 0.9 (1) & 1 & & 0.8 (1) \\
\hline Phe & $1 \cdot 0(1)$ & 1 & & $1 \cdot 1$ (1) \\
\hline His & $1.0(1)$ & 1 & $1 \cdot 3(1)$ & \\
\hline Lys & $1 \cdot 2(1)$ & 2 & $1 \cdot 1$ (1) & \\
\hline
\end{tabular}

*Value from a $24 \mathrm{~h}$ hydrolysate.

†Value from a $72 \mathrm{~h}$ hydrolysate.

FIG 3 Amino-acid sequence of the residues $\beta 121$ to 144 from haemoglobins $A$ and $K$ Woolwich. $(\downarrow)=$ major points of tryptic hydrolysis, $\quad(\downarrow)=$ minor points of tryptic hydrolysis. 
TABLE 2 Haematological findings of the proband and his family

\begin{tabular}{|c|c|c|c|c|c|c|c|c|c|c|c|c|}
\hline & \multirow[b]{2}{*}{ Age } & \multirow[b]{2}{*}{ Hb type } & \multicolumn{4}{|c|}{ Total $H b(\%)$} & \multirow[b]{2}{*}{$\begin{array}{l}R B C \\
\left(\times 10^{-12} / l\right)\end{array}$} & \multirow[b]{2}{*}{$\begin{array}{l}H b \\
(g / d l)\end{array}$} & \multirow[b]{2}{*}{$\begin{array}{l}M C H C \\
(g / d l)\end{array}$} & \multirow[b]{2}{*}{$\begin{array}{l}M C V \\
(f l)\end{array}$} & \multirow[b]{2}{*}{$\begin{array}{l}\text { Reticulocytes } \\
(\%)\end{array}$} & \multirow[b]{2}{*}{$\begin{array}{l}\text { Serum iron } \\
(\mu g / d l)\end{array}$} \\
\hline & & & $K \boldsymbol{W}$ & $A$ & $A_{2}$ & $F$ & & & & & & \\
\hline II. 1 & 72 & $\mathbf{A K W}$ & $36 \cdot 0$ & $62 \cdot 0$ & $2 \cdot 0$ & - & $4 \cdot 0$ & $13 \cdot 0$ & $32 \cdot 5$ & 100 & $1 \cdot 0$ & 58 \\
\hline II. 2 & 57 & AKW & $34 \cdot 0$ & $65 \cdot 0$ & $1 \cdot 0$ & $<1$ & $3 \cdot 9$ & $12 \cdot 0$ & $30 \cdot 7$ & 100 & $1 \cdot 6$ & 90 \\
\hline II. 3 & 62 & AKW & $37 \cdot 0$ & $61 \cdot 5$ & $2 \cdot 5$ & - & $4 \cdot 4$ & $14 \cdot 0$ & $35 \cdot 9$ & 90 & $1 \cdot 0$ & 76 \\
\hline $\begin{array}{l}\text { IIJ.3 } \\
\text { (Proband) }\end{array}$ & 37 & KWKW & $95 \cdot 6$ & - & $4 \cdot 4$ & 一 & $5 \cdot 2$ & $16 \cdot 0$ & $30 \cdot 7$ & 92 & $1 \cdot 5$ & 82 \\
\hline III. 4 & 34 & AKW & $37 \cdot 0$ & $62 \cdot 0$ & $1 \cdot 0$ & - & $4 \cdot 9$ & $16 \cdot 2$ & $33 \cdot 1$ & 85 & $1 \cdot 8$ & 54 \\
\hline III. 8 & 44 & $\mathrm{AKW}$ & $38 \cdot 0$ & $61 \cdot 5$ & 0.5 & - & $5 \cdot 3$ & $15 \cdot 7$ & $29 \cdot 6$ & 81 & 0.9 & 103 \\
\hline IV. 2 & 16 & AKW & $31 \cdot 0$ & $68 \cdot 0$ & $1 \cdot 0$ & - & $4 \cdot 3$ & $14 \cdot 2$ & $31 \cdot 2$ & 79 & $1 \cdot 4$ & 64 \\
\hline
\end{tabular}

the carboxyl side of tyrosine $\beta 130^{2}$ is absent while $\beta$ TpXIIIa ( $\beta 121$ to 130 ) is present.

(2) The minor peptide $\beta$ TpXIVb ( $\beta 140$ to 144$)$ which results from a non-specific split on the carboxyl side of asparagine $\beta 139^{16}$ is present.

(3) Two new peptides are present; peptide 2 is positively charged at $\mathrm{pH} 6.4$, and gives a staining reaction for histidine, while peptide 3 is negatively charged at $\mathrm{pH} 6.4$ and gives a staining reaction for tyrosine. Amino-acid analysis (table 1) shows that peptides 2 and 3 represent the sequences $\beta^{\mathrm{k}} 131$ to 144 and $\beta^{\mathrm{K}} 121$ to 139 , respectively (see fig 3 ). The recovery of these minor peptides was about $10 \%$ of that of peptide 1 ( $\beta^{\mathrm{K}} 121$ to 144$)$.

Fig 3 shows that the presence of $\beta^{\mathrm{A}}$ TpXIIIa and $\beta^{\mathrm{A}} \mathrm{TpXIVb}$, together with the absence of $\beta^{\mathrm{A}}$ TpXIIIb, are consistent with the substitution $\beta 132$ Lys $\rightarrow$ Gln. The amino-acid analyses of peptides 2 and 3 provide useful confirmatory evidence that the variant is $\mathrm{Hb} \mathrm{K}$ Woolwich.

The family belongs to the Attié (or Akié) tribe, which is part of the Akan people. The pedigree is shown in fig 1 . The proband (III.3) is a 37-year-old male who is married and has eight children. $\mathrm{He}$ is in good health, except for spasmodic malarial crises. His mother (II.2), his father (II.3), the sister of his father (II.1), his brother (III.4), one of his cousins (III.8), and this cousin's daughter (IV.2) were also examined. They too are all in good health. Table 2 shows the results of the haematological examinations and the haemoglobin patterns of these seven people. (The presence of $\mathrm{Hb} \mathrm{KW}$ was detected by cellulose acetate electrophoresis; $\mathrm{Hb} \mathrm{KW}$ moves slightly faster than $\mathrm{Hb} \mathrm{A}$ and is easily distinguishable from it.) It is noteworthy that all of the $\mathrm{Hb} \mathrm{KW}$ heterozygotes have low levels ( 31 to $38 \%$ ) of $\mathrm{Hb} \mathrm{KW}$, as has previously been noted by Lang et al. ${ }^{17}$ The solubility test for $\mathrm{Hb} \mathrm{KW}$ in both the oxygenated and deoxygenated form gave normal results, as did the isopropanol stability test. Functional examination of the haemoglobin from III.3 showed no abnormality (J Rosa, personal communication).

\section{Discussion}

Double heterozygotes for $\mathrm{Hb} \mathrm{KW}$ and $\mathrm{Hb} \mathrm{S}$ or $\mathrm{Hb} \mathrm{C}$ have been described before; this, however, is the first description of a $\mathrm{Hb} \mathrm{KW}$ homozygote. The family, which was discovered during a survey, lives in a traditional environment in the middle of a forest. Although $\mathrm{Hb} \mathrm{KW}$ coexists with $\mathrm{Hb} \mathrm{C}$ in a branch of the family, the combination $\mathrm{Hb} \mathrm{KW} / \mathrm{Hb}$ $\mathrm{C}$ was not observed.

Lang et al $^{17}$ consider the $\beta^{\mathrm{kw}}$ gene to be a $\beta^{+}$. thalassaemia gene on the basis of results from a family in which $\alpha$-thalassaemia and $\mathrm{Hb} \mathrm{KW}$ interacted, and in which defective synthesis of $\beta^{\mathrm{Kw}}$-chains was shown. One might then expect that a $\mathrm{Hb} \mathrm{KW}$ homozygote would show signs of $\beta$-thalassaemia. The proband (III.3) does show an increased level of $\mathrm{Hb} \mathrm{A}_{2}$, but other haematological parameters are normal. All of the $\mathrm{Hb} \mathrm{KW}$ heterozygotes show a low proportion of $\mathrm{Hb} \mathrm{KW} \mathrm{(31} \mathrm{to} 38 \%$ ) with normal or decreased levels of $\mathrm{Hb} \mathrm{A}_{2}$ and normal haematology. Clearly, without studies of globin chain synthesis, no conclusions can be drawn from this family concerning the relationship of $\mathrm{Hb} \mathrm{K}$ Woolwich to $\beta$-thalassaemia. We hope to carry out a study in the future.

Most of the $\mathrm{Hb} \mathrm{KW}$ carriers have originated from the Akan, an ethnic group of Ghana and the Ivory Coast. In Ghana, Ringelhann et $a l^{3}$ examined 24 cases of various genotypes (AKW, SKW, CKW), all of which belong to tribes of the Akan group (Kwahu-Busanga). In the Ivory Coast, of 42 subjects having $\mathrm{Hb} \mathrm{KW}, 41$ belong also to the Akan group (Baule, Appolo, Attié, Agni) but one subject is of Voltaic origin (Lobi); it is known that the Akan remained for a long time in the Volta Plateau during their migration. Thus it seems that $\mathrm{Hb} \mathrm{K}$ Woolwich is closely associated with the Akan group.

Supported in part by INSERM, Paris, France (Grant No 76.1096-1 and 2) and the Ministry of Scientific Research of the Ivory Coast (Prog No 3504). 


\section{References}

1 O'Gorman P, Allsopp KM, Lehmann H, Sukumaran PK. Sickle-cell haemoglobin K disease. $B r$ Med J 1963; 2:1381-2.

2 Allan W, Beale D, Irvine D, Lehmann H. Three haemoglobins K: Woolwich, an abnormal, Cameroon and Ibadan, two unusual variants of human haemoglobin A. Nature $1965 ; 208$ :658-61.

3 Ringelhann B, Konotey-Ahulu FID, Talapatra NC, Nkruman FK, Wiltshire BG, Lehmann H. Haemoglobin $\mathrm{K}$ Woolwich $\left(\alpha_{2} \beta_{2} 132\right.$ lysine $\rightarrow$ glutamine $)$ in Ghana. Acta Haematol $1971 ; 45: 250-8$.

4 Cabannes R, Renaud R, Mauran A, Pennors H, Charlesworth D, Price BG, Lehmann H. Deux hémoglobines rapides en Côte d'Ivoire : l'Hb KWoolwich et une nouvelle hémoglobine Hb JAbidjan ( $\alpha 51$ Gly $\rightarrow$ Asp). Nouv Rev Fr Hematol Blood Cells 1972;12:289-300.

5 Motulsky AG, Campbell-Kraut JM. In: Blumberg BS, ed. Proceedings of the Conference on Genetics, Polymorphism and Geographic Variation in Disease. New York: Grune and Stratton, 1961:159-80.

6 Marengo-Rowe AJ. Rapid electrophoresis and quantitation of haemoglobins on cellulose acetate. J Clin Pathol 1965;18:790-2.

7 Robinson AR, Robson M, Harrison AP, Zuelzer WW. A new technique for differentiation of hemoglobin. J Lab Clin Med 1957;50:745-52.

8 Schneider RG. Differentiation of electrophoretically similar hemoglobins such as $S, D, G$ and $P$; or $A_{2}, C, E$ and O. Clin Chem 1974;20:1111-5.

9 Rosemeyer MA, Heuhns ER. On the mechanism of the dissociation of haemoglobin. $J$ Mol Biol 1967;25:253-73.
10 Efremov GD, Huisman THJ, Bowman K, Wrightstone RN, Schroeder WA. Microchromatography of hemoglobin. II. A rapid method for the determination of hemoglobin $\mathrm{A}_{2}$. J Lab Clin Med 1974;83:657-72.

11 Singer H, Chernoff AI, Singer L. Studies on abnormal hemoglobin. I. Their demonstration in sickle cell anemia and other hematologic disorders by means of alkali denaturation. Blood 1951;6:413-28.

12 Itano HA. Solubilities of naturally occurring mixtures of human hemoglobin. Arch Biochem 1953;47:148-59.

13 Carrell RW, Kay R. A simple method for the detection of unstable haemoglobins. Br J Haematol 1972;23:615-9.

14 Clegg JB, Naughton MA, Weatherall DJ. Abnormal human haemoglobins. Separation and characterisation of the $\alpha$ - and $\beta$-chains by chromatography and the determination of two new variants, $\mathrm{Hb}$ Chesapeake and $\mathrm{Hb} \mathrm{J}$ (Bangkok). J Mol Biol 1966;19:91-108.

15 Sick K, Beale D, Irvine D, Lehmann H. Haemoglobin G Copenhagen and haemoglobin J Cambridge. Two new $\beta$-chain variants of haemoglobin A. Biochim Biophys Acta $1967 ; 140: 231-42$.

16 Beutler E, Lang A, Lehmann H. Hemoglobin Duarte $\left(\alpha_{2} \beta_{2}{ }^{62(\mathrm{E} 6)} \mathrm{Ala} \rightarrow\right.$ Pro $):$ a new unstable hemoglobin with increased oxygen affinity. Blood 1974;43:527-35.

17 Lang A, Lehmann H, King-Lewis PA. Hb K Woolwich the cause of a thalassaemia. Nature $1974 ; 249$ :467-9.

Requests for reprints to Professor H Lehmann, Department of Biochemistry, University of Cambridge, Tennis Court Road, Cambridge CB2 1QW. 